\title{
Полиморфизм генов хемокиновых рецепторов CCR5 и CCR2 у больных бронхиальной астмой и их родственников
}

1 - ГОУ ВПО "Красноярский государственный медицинский университет им. проф. В.Ф.Войно-Ясенецкого": 660022, Красноярск, ул. Партизана Железняка, 1; 2 - ГУ "НИИ терапии СО РАМН": 630089, Новосибирск, ул. Бориса Богаткова, 175 / 1;

3 - кафедра терапии ФПК и ППВ ГОУ ВПО "Новосибирский государственный медицинский университет": 630082, Новосибирск, ул. Вавилова, 14

\section{I.I.Cherkashina, S.Yu.Nikulina, V.A.Shulman, N.I.Logvinenko, V.N.Maksimov, M.I.Voevoda, A.A.Chernova Chemokine receptor CCR5 and CCR2 gene polymorphism in patients with bronchial asthma an their relatives}

\begin{abstract}
Summary
Family study of 62 probands with bronchial asthma (BA) and their $1721^{\text {st }}$ to $3^{\text {rd }}$ degree relatives (the study group) was performed. A control group included persons not having any respiratory disease. Typical investigations for patients with BA, molecular and statistical methods were used. Findings of chemokine receptor CCR5 and CCR2 gene polymorphism in asthma patients and their relatives in comparison to the controls have been shown in this paper. The chemokine receptor CCR5 gene polymorphism in the coding area was associated with asthma and was an important component of hereditary predisposition to this disease. Statistically significant differences were found in frequency distributions of gene CCR2 alleles between relatives having allergy and healthy relatives. One could suppose that carriage of allele 641 of CCR2 gene could be a predisposing factor for allergy occurrence.

Key words: gene polymorphism, chemokine receptor, bronchial asthma, heredity.
\end{abstract}

\section{Резюме}

Проведено семейное обследование 62 пробандов, у которых была диагностирована бронхиальная астма (БА), и их 172 родственников I, II, III степени родства (основная группа). В контрольную группу вошли лица без заболеваний бронхолегочной системы. В работе использовался общепринятый комплекс обследования лиц, страдающих БА, молекулярно-генетические методы исследования, а также методы статистической обработки данных. Был изучен полиморфизм генов хемокиновых рецепторов CCR5 и CCR2 у больных БА и их родственников в сравнении с группой контроля. Установлено, что полиморфизм гена хемокинового рецептора CCR5 в кодирующей области ассоциирован с БА и является важной компонентой наследственной предрасположенности к этому заболеванию. Обнаружены статистически значимые различия в распределении частот аллелей гена CCR2 между группами родственников с аллергией и здоровыми родственниками. Можно предположить, что носительство аллеля 64I гена CCR2 является предрасполагающим фактором развития аллергии.

Ключевые слова: полиморфизм генов, хемокиновые рецепторы, бронхиальная астма, наследственность.

Бронхиальная астма (БА) по-прежнему остается одной из самых важных проблем пульмонологии. Постоянный рост заболеваемости БА во всем мире делает актуальным изучение факторов, способствующих формированию этой патологии. Молекулярно-генетические исследования убедительно подтвердили вовлечение в патогенез БА генетических факторов [1, 2]. Во многих из них установлена ассоциация полиморфизма различных генов с БА [3-6]. В последнее время внимание исследователей привлечено к генам хемокиновых рецепторов CCR5 и CCR2.

Ген CCR5 локализован на 3-й хромосоме в регионе p21.3. CCR5 представляет собой трансмембранный белок, состоящий из 352 аминокислотных остатков [7]. CCR5 размещается преимущественно на поверхности активированных моноцитов (макрофагов), дендритных клеток и Т-лимфоцитов [8]. В норме рецептор CCR5 связывает хемокиновые лиганды макрофагальных воспалительных белков (MIP-1 $\alpha$, МIP-1 $\beta$ ), моноцит хемотаксических белков (МСР) 2, 4 , RANTES и посредством этого участвует в активации иммунокомпетентных клеток и их миграции в очаг воспаления [9]. В гене CCR5 в настоящее время известны > 20 мутаций и полиморфизмов. Описана делеция 32 пар нуклеотидов (п. н.) в кодирующей области гена CCR5 (del32CCR5), приводящая к трансляции укороченного варианта белка, не адгезирующегося на поверхности клеток. В различных популяциях частота делеционного аллеля гена CCR5 варьирует от 15,5 до $16 \%$ и зависит от этнического состава населения [10-12].

Известно, что нарушение функции рецептора CCR5 в результате делеции 32 п. н. может выступать патогенетически значимым фактором развития заболеваний. Полиморфизм гена хемокинового рецептоpa CCR5 хорошо изучен при ВИЧ-инфекции [10, 13, 14]. Люди, гомозиготные по этой делеции, не могут заболеть СПИДом, связанным с инфекцией ВИЧ-1, даже если они входят в группу высокого риска, в то же время гетерозиготы обладают частичной устойчивостью к инфекции $[10,13,14]$. Имеются данные об ассоциации полиморфизма гена CCR5 с рассеянным склерозом [15], с раком легкого, молочной железы, с меланомой [16-18] и с внебольничной пневмони- 
ей [19, 20]. Рядом исследователей показана протективная роль делеционного аллеля гена CCR5 в развитии гипертонической болезни и ишемической болезни сердца [21-23]. Результаты опубликованных работ по ассоциации CCR5del32 с риском заболевания БА противоречивы, особенно в различных по этническому составу популяциях $[18,24]$.

Известно, что инфильтрация тканей легких эозинофилами у больных БА ассоциирована с повышенной экспрессией хемокинов СС-семейства: МСР-3, MCP-4 и RANTES. Дефицит экспрессии CCR5 на клетках может снижать хемотаксический потенциал указанных хемокинов. Установлено, что нейтрализация RANTES у мышей уменьшает гиперреактивность бронхов, а у мышей с удалением гена CCR5, кодирующего белок-рецептор для RANTES, понижен уровень воспалительных клеток и их медиаторов в респираторном тракте. Эти данные подтверждают, что наличие дефектного аллеля CCR5del32 может снижать риск БА [18].

Имеются сведения о более низкой частоте встречаемости делеционного аллеля гена хемокинового рецептора CCR5 у больных БА по сравнению с популяционным контролем в Западно-Сибирском регионе РФ и об ассоциации CCR5del32 с низким риском формирования БА атопического генеза [18]. Наряду с этим собраны данные об ассоциации делеционного аллеля гена хемокинового рецептора CCR5 с более тяжелым течением заболевания, очень ранней или очень поздней манифестацией атопического диатеза и синдрома бронхообструкции у детей, что дает основания считать его предиктором перечисленных состояний [24]. Кроме того, в ряде работ, проведенных в других популяциях, не выявлено статистической разницы в частоте CCR5del32 у здоровых лиц и больных БА [24]. Возможно, это связано с этнической неоднородностью обследуемых, а также с участием других механизмов формирования БА у взрослых.

Ген CCR2 также локализован на 3-й хромосоме. B клетках синтезируются 2 изоформы рецептора: CCR2A и CCR2B. Обе изоформы рецептора связываются с моноцит-хемотаксическими белками (МСР) 1, 2, 3 и 4. CCR2 экспрессируется в моноцитах, макрофагах, Т-лимфоцитах и регулирует привлечение воспалительных клеток и их функционирование на участках воспалительного ответа [25]. Мутантная форма гена CCR2 641 образуется в результате замены нуклеотида $G$ на А в позиции 190, что в свою очередь приводит к замене аминокислоты валина на изолейцин в 64-й позиции (CCR2-64I) в первичной последовательности белка-рецептора.

Среди европеоидов аллельная частота CCR2 64I составляет 9,8\%, среди афроамериканцев - 17,2 \%, среди монголоидов - $25 \%$ [26]. Исследования последних лет выявили ассоциацию этой мутации с атеросклерозом коронарных сосудов, сахарным диабетом, инфарктом миокарда, продолжительностью жизни [27], пневмонией [19, 20] и саркоидозом [25].

Имеются единичные указания, что CCR2 и их рецепторы вовлечены в формирование аллергической БА [28].
В целом полиморфизм генов хемокиновых рецепторов CCR5 и CCR2 у больных БА и их родственников изучен недостаточно, их роль в патогенезе заболевания еще окончательно не определена.

Целью настоящего исследования явилось изучение частоты распределения генотипов и аллелей полиморфизма генов хемокиновых рецепторов CCR5 и CCR2 у больных БА и их родственников.

\section{Материалы и методы}

Исследование проведено среди 62 семей больных БА (235 человек), проживающих в Красноярске. В каждой семье выделялся пробанд с верифицированной БА. В основную группу вошли 62 больных с БА и 173 их родственника I, II, III степени родства, в т. ч. 81 мужчина (34,47 \%) и 154 женщины (65,53\%). Средний возраст пробандов составил 46,57 $\pm 2,49$ года, родственников $-31,30 \pm 1,73$ года. Набор пробандов производился в течение их стационарного лечения в пульмонологическом отделении МУЗ "ГКБ № 20".

Среди всех родственников были выделены лица с БА, другими различными аллергическими заболеваниями (аллергический ринит, атопический дерматит и др.) и без заболеваний бронхолегочной системы. В дальнейшем родственники с БА (28 человек) были отнесены к группе пробандов.

Диагноз БА устанавливался в соответствии с Глобальной стратегией лечения и профилактики БА (GINA 2002 г. и 2006 г.) [29, 30] на основании жалоб на приступы затрудненного дыхания или приступообразный кашель, купируюшиеся ингаляцией $\beta_{2}$-агонистов, наличия обратимой бронхиальной обструкции, подтвержденной объективными методами обследования (суточный разброс пиковой скорости выдоха > $20 \%$, прирост объема форсированного выдоха за $1-ю$ с $>15 \%$ ).

Среди наблюдавшихся больных диагностированы следующие формы БА (в соответствии с Международной классификацией болезней 10-го пересмотра): аллергическая - у 73 человек (81,1 \%), неаллергическая - у 17 (18,9\%). Степень тяжести БА у 40 человек (44,4 \%) была легкой, у 34 (37,8 \%) среднетяжелой и у $16(17,8 \%)$ - тяжелой. Среди обследованных легкое обострение БА регистрировалось у 12 (13,3 \%) человек, среднетяжелое - у 49 $(54,4 \%)$, тяжелое - $8(8,9 \%)$. Не было обострения у $21(23,3 \%)$ больного. Средний стаж БА у пробандов составил $12,7 \pm 1,2$ года, у родственников $15,90 \pm 2,21$ года.

Комплексное обследование включало в себя: клиническое динамическое наблюдение; изучение клинических анализов крови, мокроты; рентгенографию органов грудной клетки и придаточных пазух носа (по клиническим показаниям); оценку параметров функции внешнего дыхания посредством компьютерной спирографии.

При оценке полиморфизма генов у больных БА и их родственников в качестве контроля использовали популяционную выборку здоровых лиц, жителей Октябрьского района Новосибирска ( $n=464$; средний 
возраст - 32,70 \pm 7,36 года). Данные предоставлены НИИ терапии СО РАМН (Новосибирск).

Молекулярно-генетические исследования проведены на базе НИИ терапии СО РАМН (Новосибирск). Для проведения молекулярно-генетического анализа были взяты образцы венозной крови в количестве 5-0 мл. Выделение ДНК проводили стандартным методом с фенол-хлороформной экстракцией. Генотипирование осуществляли с помощью полимеразной цепной реакции по опубликованной методике [31].

Статистическая обработка материала проводилась с использованием пакета прикладных программ SPSS-13 и Excel (2002). Различия в распределении частот аллелей и генотипов гена CCR5 между группами оценивали посредством критерия $\chi^{2}$ и точного 2-стороннего критерия Фишера. Различия считали статистически значимыми при $p<0,05$.

\section{Результаты и обсуждение}

Частоты генотипов I / D полиморфизма гена CCR5 и V64I полиморфизма гена CCR2 в популяции Новосибирска находились в равновесии Харди-Вайнберга. Результаты анализа I / D полиморфизма гена хемокинового рецептора CCR5 в кодирующей области среди больных БА, их родственников и в контрольной группе представлены в табл. 1 .

Установлено, что частота носителей гомозиготного генотипа по распространенному аллелю (II) среди больных БА $(86,7 \pm 3,7 \%)$ была несколько выше по сравнению с контрольной выборкой (78,3 \pm $2,6 \% ; p=0,209)$. Также отмечена явная тенденция к снижению носителей гетерозиготного генотипа ID среди пациентов с БА $(13,3 \pm 3,5 \%)$ в сравнении с группой контроля $(21,3 \pm 2,5 \% ; p=0,092)$. Частота генотипов ID и DD у больных БА была ниже (13,3 $3,5 \%)$, чем в группе контроля $(21,7 \pm 2,5 \%$; ОШ = 1,799; 95\%-ный ДИ - 0,9-3,5; $p=0,092)$.
Анализ частот встречаемости аллелей гена CCR5 в изучаемых группах позволил выявить отличие частоты аллелей в выборке пробандов от контрольной группы. Среди пробандов носители аллеля D гена CCR5 встречались в 1,6 раза реже, чем в группе контроля: у 6,7 $\pm 1,9 \%$ (12 человек) и $11,0 \pm 1,4 \%$ (58 человек) соответственно (ОШ $=0,567 ; 95 \%$-ный ДИ $-0,302-1,100 ; p=0,11)$.

Была проанализирована частота аллелей и генотипов I / D полиморфизма гена CCR5 у пациентов c аллергической и неаллергической формами БА (табл. 2). Среди больных аллергической БА достоверно преобладал II генотип $(90,4 \pm 3,5 \%)$ гена CCR5 по сравнению с контрольной группой (78,3 \pm $2,6 \%)$ и больными неаллергической БА (70,6 \pm $1,1 \%)$. У пациентов с неаллергической БА была повышена доля ID генотипа $(29,4 \pm 1,0 \%)$ и аллеля D $(14,7 \pm 5,5 \%)$ по сравнению с контрольной группой $(21,3 \pm 2,5 \%)$ и больными аллергической БА $(9,6 \pm$ $3,3 \%)$. У больных аллергической БА частота аллеля D была существенно ниже, чем в популяционном контроле $(4,8 \pm 1,4 \%$ и 11,0 $\pm 1,6 \%$ соответственно; ОШ $=0,406 ; 95 \%$-ный ДИ - 0,181-0,910; $p=0,026)$.

Распределение генотипов и аллелей I / D полиморфизма гена CCR5 у больных с различной степенью тяжести БА представлено в табл. 3. Анализ распределения генотипов полиморфизма гена CCR5 у пациентов с БА показал статистически значимую ассоциацию генотипа II с легким течением заболевания. Носителей генотипа II среди больных легкой БА было достоверно больше в сравнении с контрольной группой $(92,5 \pm 4,3 \% ; p=0,034)$. Аллель I у пациентов с легкой БА встречался также значимо чаще, чем в контрольной выборке $(96,3 \pm 2,2 \%$; $p=0,045)$. При этом в группе больных БА по мере нарастания степени тяжести патологии прослеживалась тенденция к накоплению гетерозиготного генотипа ID и аллеля D. Частота гетерозиготного геноти-

Таблица 1 Распределение частоты генотипов и аллелей полиморфизма гена CCR2 в исследуемых группах, $M \pm m$

\begin{tabular}{|c|c|c|c|c|}
\hline Генотипы & $\begin{array}{c}\text { Контроль }(n=464), \\
\%(n)\end{array}$ & $\begin{array}{c}\text { БA }(n=90) \\
\%(n)\end{array}$ & $\begin{array}{c}\text { Родственники с аллергией }(n=55), \\
\text { \% (n) }\end{array}$ & $\begin{array}{c}\text { 3доровые родственники }(n=87) \\
\%(n)\end{array}$ \\
\hline II & $78,3 \pm 2,6(206)$ & $86,7 \pm 3,7(78)$ & $74,5 \pm 5,9(41)$ & $85,1 \pm 3,8(74)$ \\
\hline ID & $21,3 \pm 2,5(56)$ & $13,3 \pm 3,5(12)$ & $23,6 \pm 5,7(13)$ & $13,8 \pm 3,6(12)$ \\
\hline DD & $0,4 \pm 0,2(1)$ & $0(0)$ & $1,8(1)$ & $1,1(1)$ \\
\hline$p$ & & 0,209 & 0,429 & 0,230 \\
\hline \multicolumn{5}{|l|}{ Аллели } \\
\hline 1 & $89,0 \pm 1,4(468)$ & $93,3 \pm 1,9(168)$ & $86,4 \pm 3,3$ (95) & $92,0 \pm 2,1(160)$ \\
\hline D & $11,0 \pm 1,4(58)$ & $6,7 \pm 1,9(12)$ & $13,6 \pm 3,3(15)$ & $8,0 \pm 2,1(14)$ \\
\hline 2-сторонний тест Фишера & & 0,111 & 0,415 & 0,314 \\
\hline ОШ & & 0,576 & 0,785 & 0,706 \\
\hline 95\%-ный ди & & $0,302-1,1$ & $0,427-1,443$ & $0,383-1,30$ \\
\hline Носители генотипа II & $78,3 \pm 2,6(206)$ & $86,7 \pm 3,6(78)$ & $74,5 \pm 5,4(41)$ & $85,1 \pm 3,8(74)$ \\
\hline Носители других генотипов & $21,7 \pm 2,6(57)$ & $13,3 \pm 3,6(12)$ & $25,5 \pm 5,4(14)$ & $14,9 \pm 3,8(13)$ \\
\hline 2-сторонний тест Фишера & & 0,092 & 0,593 & 0,216 \\
\hline ОШ & & 1,799 & 1,234 & 1,575 \\
\hline 95\%-ный ди & & $0,916-3,532$ & $0,629-2,421$ & $0,815-3,042$ \\
\hline
\end{tabular}

Примечание: $p$ - уровень значимости при сравнении распределения генотипов с показателями группы контроля; ОШ - отношение шансов; 95\%-ный ДИ - 95\%-ный доверительный интервал. 
Таблица 2

Распределение генотипов и частоты аллелей гена CCR5 среди больных БА и в контрольной группе, $М \pm$ m

\begin{tabular}{|c|c|c|c|c|c|c|}
\hline \multirow[b]{2}{*}{ Генотипы } & \multicolumn{2}{|c|}{ Контрольная группа ( $n=263)$} & \multicolumn{2}{|c|}{ Аллергическая БА ( $n=73)$} & \multicolumn{2}{|c|}{ Неаллергическая БА $(n=17)$} \\
\hline & $n$ & $\%$ & $n$ & $\%$ & $n$ & $\%$ \\
\hline II & 206 & $78,3 \pm 2,6$ & 66 & $90,4 \pm 3,5$ & 12 & $70,6 \pm 1,1$ \\
\hline ID & 56 & $21,3 \pm 2,5$ & 7 & $9,6 \pm 3,3$ & 5 & $29,4 \pm 1,0$ \\
\hline DD & 1 & $0,4 \pm 0,2$ & - & - & - & - \\
\hline$p$ & & & \multicolumn{2}{|c|}{0,064} & \multicolumn{2}{|c|}{0,715} \\
\hline \multicolumn{7}{|l|}{ Аллели } \\
\hline I & 468 & $89,0 \pm 1,4$ & 139 & $95,2 \pm 1,8$ & 29 & $85,3 \pm 6,0$ \\
\hline D & 58 & $11,0 \pm 1,4$ & 7 & $4,8 \pm 1,8$ & 5 & $14,7 \pm 6,0$ \\
\hline 2-сторонний тест Фишера & & & \multicolumn{2}{|c|}{$0,026^{*}$} & \multicolumn{2}{|c|}{0,572} \\
\hline ОШ & & & \multicolumn{2}{|c|}{0,406} & \multicolumn{2}{|c|}{1,391} \\
\hline 95\%-ный ди & & & \multicolumn{2}{|c|}{$0,181-0,91$} & \multicolumn{2}{|c|}{$0,518-3,735$} \\
\hline Носители генотипа II & 206 & $78,3 \pm 2,5$ & 66 & $90,4 \pm 3,4$ & 12 & $70,6 \pm 1,0$ \\
\hline Носители других генотипов & 57 & $21,7 \pm 2,5$ & 7 & $9,6 \pm 3,4$ & 5 & $29,4 \pm 1,0$ \\
\hline 2-сторонний тест Фишера & & & \multicolumn{2}{|c|}{$0,019^{*}$} & \multicolumn{2}{|c|}{0,545} \\
\hline Ш & & & \multicolumn{2}{|c|}{0,383} & \multicolumn{2}{|c|}{1,506} \\
\hline 95\%-ный ДИ & & & \multicolumn{2}{|c|}{$0,167-0,881$} & \multicolumn{2}{|c|}{$0,509-4,451$} \\
\hline
\end{tabular}

Примечание: $p$ - уровень значимости при сравнении распределения генотипов с показателями группы контроля; * - достигнутый уровень значимости при сравнении частоты генотипов и аллелей с показателями группы контроля.

па (ID) составила 7,5 \pm 4,0\% у пациентов с легкой БА $(p=0,07) ; 17,6 \pm 6,4 \%$ - со среднетяжелой $(p=0,79)$ и $18,7 \pm 9,6 \%-$ с тяжелой БА $(p=0,94)$. Частота делеционного аллеля (D) равнялась $3,7 \pm$ $1,9 \%$ у пациентов с легкой БА $(p=0,07) ; 8,8 \pm$ $3,3 \%$ - со среднетяжелой $(p=0,73)$ и 9,4 $\pm 5,0 \%-$ с тяжелой БА $(p=0,99)$, как показано в табл. 3.

Изучен I / D полиморфизм гена CCR5 у родственников пробандов I, II и III степени родства (табл. 1). Распределение частот генотипов гена хемокинового рецептора CCR5 в выборке родственников с аллергическими заболеваниями и контрольной группе статистически достоверно не отличалось $(p=0,429)$. В обеих популяциях преобладал гомозиготный генотип II (74,5 \pm 5,9 \% и 78,3 $\pm 2,6 \%$ соответственно).
Суммарное значение частот гетерозиготного генотипа (ID) и гомозиготного генотипа (DD) по редкому аллелю (носители других генотипов) встречалось несколько чаще у родственников с признаками атопии $(25,5 \pm 5,8 \%)$, чем в группе контроля $(21,7 \pm$ $2,5 \%)$, но статистически достоверных различий не получено (ОШ = 1,234; 95\%-ный ДИ - 0,629-2,421; $p=0,593)$.

Среди здоровых родственников носители генотипов ID и DD встречались реже $(14,9 \pm 3,7 \%)$, чем в контрольной группе $(21,7 \pm 2,5 \%)$, но статистически достоверных различий также не получено $(О Ш=1,575 ; 95 \%$-ный ДИ - 0,815-3,042; $p=0,216)$, как показано в табл. 1. В группе здоровых родственников и контрольной выборке частота гомозиготного

Таблица 3 Распределение генотипов и частоты аллелей гена CCR5 среди больных БА разной степени тяжести и в контрольной группе, $M \pm m$

\begin{tabular}{|c|c|c|c|c|}
\hline Генотипы & Контроль ( $n=263), \%$ (n) & Легкая БА $(n=40), \%(n)$ & Средняя БА (n= 34), \% (n) & Тяжелая БА ( $n=16), \%$ (n) \\
\hline II & $78,3 \pm 2,6(206)$ & $92,5 \pm 4,3(37)$ & $82,4 \pm 6,6(28)$ & $81,3 \pm 9,8(13)$ \\
\hline ID & $21,3 \pm 2,5(56)$ & $7,5 \pm 4,0(3)$ & $17,6 \pm 6,4(6)$ & $18,7 \pm 9,6(3)$ \\
\hline DD & $0,4 \pm 0,2(1)$ & - & - & - \\
\hline$p$ & & 0,110 & 0,826 & 0,940 \\
\hline \multicolumn{5}{|l|}{ Аллели } \\
\hline I & $89,0 \pm 1,4(468)$ & $96,3 \pm 2,1(77)$ & $91,2 \pm 3,4(62)$ & $90,6 \pm 5,2(29)$ \\
\hline D & $11,0 \pm 1,4(58)$ & $3,7 \pm 2,1(3)$ & $8,8 \pm 3,4(6)$ & $9,4 \pm 5,2(3)$ \\
\hline 2-сторонний тест Фишера & & $0,045^{*}$ & 0,682 & 1,0 \\
\hline ㅇ & & 0,314 & 0,781 & 0,835 \\
\hline 95\%-ный ди & & $0,096-1,028$ & $0,323-1,885$ & $0,247-2,826$ \\
\hline Носители генотипа II & $78,3 \pm 2,5(206)$ & $92,5 \pm 4,2(37)$ & $82,4 \pm 6,5(28)$ & $81,3 \pm 9,7(13)$ \\
\hline Носители других генотипов & $21,7 \pm 2,5(57)$ & $7,5 \pm 4,2(3)$ & $17,6 \pm 6,5(6)$ & $18,7 \pm 9,7(3)$ \\
\hline 2-сторонний тест Фишера & & $0,034^{*}$ & 0,663 & 1,0 \\
\hline ош & & 0,293 & 0,774 & 0,834 \\
\hline 95\%-ный ди & & $0,087-0,985$ & $0,306-1,961$ & $0,230-3,027$ \\
\hline
\end{tabular}

Примечание: p - уровень значимости при сравнении распределения генотипов с показателями группы контроля; * - достигнутый уровень значимости при сравнении частоты генотипов и аллелей с показателями группы контроля. 
Распределение частоты генотипов и аллелей полиморфизма гена CCR2 в исследуемых группах, $M \pm m$

\begin{tabular}{|c|c|c|c|c|}
\hline Генотипы & $\begin{array}{c}\text { Контроль }(n=464), \\
\%(n)\end{array}$ & $\begin{array}{c}\text { БA }(n=90) \\
\%(n)\end{array}$ & $\begin{array}{l}\text { Родственники с аллергией }(n=58), \\
\text { \% (n) }\end{array}$ & $\begin{array}{c}\text { Здоровые родственники }(n=87) \text {, } \\
\%(n)\end{array}$ \\
\hline $64 V / V$ & $78,9 \pm 1,9(366)$ & $78,9 \pm 4,4(71)$ & $67,2 \pm 6,2(39)$ & $82,8 \pm 4,0(72)$ \\
\hline $64 \mathrm{~V} / \mathrm{I}$ & $19,0 \pm 1,8(88)$ & $20,0 \pm 4,2(18)$ & $27,6 \pm 5,8(16)$ & $16,1 \pm 3,9(14)$ \\
\hline $64 I / I$ & $2,1 \pm 1,4(10)$ & $1,1 \pm 1,0(1)$ & $5,2 \pm 2,9(3)$ & $1,1 \pm 1,1(1,1)$ \\
\hline$p$ & & 0,796 & 0,095 & 0,658 \\
\hline \multicolumn{5}{|l|}{ Аллели } \\
\hline V & $88,4 \pm 1,1(820)$ & $88,9 \pm 2,4(160)$ & $81,0 \pm 3,6(94)$ & $91,9 \pm 2,1(158)$ \\
\hline I & $11,6 \pm 1,1(108)$ & $11,1 \pm 2,4(20)$ & $19,0 \pm 3,6(22)$ & $8,1 \pm 2,1(14)$ \\
\hline 2-сторонний тест Фишера & & 0,899 & $0,035^{*}$ & 0,233 \\
\hline ОШ & & 0,949 & 0,563 & 0,673 \\
\hline 95\%-ный ди & & $0,572-1,575$ & $0,339-0,933$ & $0,376-1,204$ \\
\hline Носители генотипа 64V / 64V & $78,9 \pm 1,9(366)$ & $78,9 \pm 4,3(71)$ & $67,2 \pm 6,2(39)$ & $82,8 \pm 4,0(72)$ \\
\hline Носители других генотипов & $21,1 \pm 1,9(98)$ & $21,1 \pm 4,3(19)$ & $32,8 \pm 6,2(19)$ & $17,2 \pm 4,0(15)$ \\
\hline 2-сторонний тест Фишера & & 1,0 & 0,065 & 0,471 \\
\hline ОШ & & 0,999 & 0,550 & 0,778 \\
\hline 95\%-ный дИ & & $0,575-1,738$ & $0,304-0,993$ & $0,427-1,417$ \\
\hline
\end{tabular}

Примечание: p - уровень значимости при сравнении распределения генотипов с показателями группы контроля; * - достигнутый уровень значимости при сравнении частоты аллелей с показателями группы контроля.

генотипа II достигала $85,1 \pm 3,8 \%$ и 78,3 $\pm 2,6 \%$ coответственно.

Различия в распространенности аллелей между контрольной группой и выборкой родственников с аллергическими заболеваниями и здоровыми родственниками не получены. Отмечено, что носителей аллеля D в группе здоровых родственников было значительно меньше $(8,0 \pm 2,4 \%)$ в сравнении с контролем $(11,0 \pm 1,4 \%$; ОШ $=0,706 ; 95 \%$-ный ДИ - 0,383-1,300; $p=0,314)$.

Результаты анализа полиморфизма гена хемокинового рецептора CCR2 в кодирующей области у больных БА и в контрольной группе представлены в табл. 4. Частота распространения гомозиготного генотипа по распространенному аллелю у больных БА $(64 \mathrm{~V} / \mathrm{V})$ составила 78,9 $\pm 4,4 \%$ (71 человек), гетерозиготного генотипа $(64 \mathrm{~V} / \mathrm{I})-20,0 \pm 4,2 \%$ (18 человек), гомозиготного генотипа по редкому аллелю (64I / I) - 1,1 $\pm 1,0$ \% (1 человек).
В контрольной группе генотипы были распределены следующим образом: 78,9 $\pm 1,9 \%$ (366 человек) являлись гомозиготами по распространенному аллелю $(64 \mathrm{~V} / \mathrm{V}), 19,0 \pm 1,8 \%$ (88 человек) - гетерозиготами $(64 \mathrm{~V} / \mathrm{I})$ и $2,2 \pm 1,4 \%$ (10 человек) - гомозиготами по редкому аллелю (64I / I). В ходе сравнительного анализа частот генотипов статистически достоверных различий между больных БА и контрольной группой не обнаружено (ОШ $=0,999$; $95 \%$-ный ДИ - 0,575-1,738; $p=1,0$; табл. 4).

Частота встречаемости носителей распространенного аллеля (CCR2-64V) у больных БА составила $88,9 \pm 2,4 \%$ (160 человек), в контрольной группе $88,4 \pm 1,1 \%$ (820 человек). Частота распространения носителей редкого аллеля (CCR2-64I) была следующей: среди больных БА - 11,1 $\pm 2,3 \%$ (20 человек), в контрольной группе - 11,6 $\pm 1,0 \%$ (108 человек). Таким образом, при изучении данных по носительству аллелей V и I достоверных различий между боль-

Таблища 5

Распределение генотипов и частоты аллелей гена CCR2 среди больных с разными формами БА и в контрольной группе, $M \pm m$

\begin{tabular}{|c|c|c|c|c|c|c|}
\hline \multirow[t]{2}{*}{ Генотипы } & \multicolumn{2}{|c|}{ Контрольная группа ( $n=464)$} & \multicolumn{2}{|c|}{ Аллергическая БА (n= 73) } & \multicolumn{2}{|c|}{ Неаллергическая БА ( $=17)$} \\
\hline & $n$ & $\%$ & $n$ & $\%$ & $n$ & $\%$ \\
\hline $64 \mathrm{~V} / \mathrm{V}$ & 366 & $78,9 \pm 1,9$ & 58 & $79,4 \pm 4,8$ & 13 & $76,5 \pm 0,4$ \\
\hline $64 \mathrm{~V} / \mathrm{I}$ & 88 & $19,0 \pm 1,8$ & 14 & $19,2 \pm 4,6$ & 4 & $23,5 \pm 0,2$ \\
\hline $641 / 1$ & 10 & $2,2 \pm 1,4$ & 1 & $1,4 \pm 1,2$ & - & - \\
\hline$p$ & & & \multicolumn{2}{|c|}{0,908} & \multicolumn{2}{|c|}{0,757} \\
\hline \multicolumn{7}{|l|}{ Аллели } \\
\hline v & 820 & $88,4 \pm 1,1$ & 130 & $89,6 \pm 2,5$ & 30 & $88,2 \pm 5,5$ \\
\hline I & 108 & $11,6 \pm 1,1$ & 15 & $10,3 \pm 2,5$ & 4 & $11,8 \pm 5,5$ \\
\hline 2-стороний тест Фишера & & & \multicolumn{2}{|c|}{0,779} & \multicolumn{2}{|c|}{1,000} \\
\hline ОШ & & & \multicolumn{2}{|c|}{0,876} & \multicolumn{2}{|c|}{1,012} \\
\hline 95\%-ный дИ & & & \multicolumn{2}{|c|}{$0,495-1,550$} & \multicolumn{2}{|c|}{$0,350-2,929$} \\
\hline
\end{tabular}

Примечание: $p$ - уровень значимости при сравнении распределения генотипов с показателями группы контроля. 
Распределение генотипов и частоты аллелей гена CCR2 среди больных БА разной степени тяжсести и в контрольной группе, $M \pm m$

\begin{tabular}{|c|c|c|c|c|}
\hline Генотипы & Контроль (n= 464), \% (n) & Легкая БА ( $n=40), \%$ (n) & Средняя БА $(n=34), \%$ (n) & Тяжелая БА ( $n=16), \%$ (n) \\
\hline $64 V / V$ & $78,9 \pm 1,9(366)$ & $72,5 \pm 7,1(29)$ & $85,3 \pm 6,1(29)$ & $81,25 \pm 9,8(13)$ \\
\hline $64 \mathrm{~V} / \mathrm{I}$ & $19,0 \pm 1,9(88)$ & $25,0 \pm 6,8(10)$ & $14,7 \pm 6,1(5)$ & $18,75 \pm 9,6(3)$ \\
\hline $64 I / I$ & $2,2 \pm 1,4(10)$ & $2,5 \pm 2,5(1)$ & - & - \\
\hline$p$ & & 0,637 & 0,547 & 1,0 \\
\hline \multicolumn{5}{|l|}{ Аллели } \\
\hline v & $88,4 \pm 1,1(820)$ & $86,1 \pm 3,9(68)$ & $92,6 \pm 3,2(63)$ & $90,6 \pm 5,2(29)$ \\
\hline I & $11,6 \pm 1,1(108)$ & $13,9 \pm 3,9(11)$ & $7,4 \pm 3,2(5)$ & $9,4 \pm 5,2(3)$ \\
\hline 2-сторонний тест Фишера & & 0,585 & 0,426 & 1,0 \\
\hline Ош & & 1,228 & 0,603 & 0,785 \\
\hline 95\%-ный ди & & $0,630-2,395$ & $0,237-1,531$ & $0,235-2,622$ \\
\hline Носители генотипа V / V & & $72,5 \pm 7,1(29)$ & $85,3 \pm 6,1(29)$ & $81,25 \pm 9,80(13)$ \\
\hline Носители других генотипов & & $27,5 \pm 7,1(11)$ & $14,7 \pm 6,1(5)$ & $18,75 \pm 9,60(3)$ \\
\hline 2-сторонний тест Фишера & & 0,325 & 0,511 & 1,0 \\
\hline ош & & 1,417 & 0,644 & 0,862 \\
\hline 95\%-ный ди & & $0,683-2,937$ & $0,243-1,707$ & $0,241-3,084$ \\
\hline
\end{tabular}

Примечание: р - уровень значимости при сравнении распределения генотипов с показателями группы контроля.

ными БА и контрольной группой выявлено не было $(\mathrm{OШ}=0,949 ; 95 \%$-ный ДИ - 0,572-1,575; $p=0,899)$.

Проведено сравнение распределения частот генотипов и аллелей гена CCR2 у больных аллергической и неаллергической БА и в контрольной группе. Среди пациентов с неаллергической БА частота генотипа 64V / I гена CCR2 превышала таковую в контрольной группе, но различия не достигали статистической достоверности $(23,5 \pm 0,2 \%$ и $19,0 \pm 1,8 \%$; $p=0,757)$. У больных аллергической БА и у лиц контрольной группы распределение частот генотипов гена CCR2 было сходным (19,2 \pm 4,6 \% и 19,2 \pm $4,6 \%$ соответственно; $p=0,908)$, как показано в табл. 5. Частота вариантного аллеля I была несколько ниже у больных аллергической БА $(10,3 \pm$ $2,5 \%)$, чем у пациентов с неаллергической БА $(11,8 \pm$ $3,4 \%)$ и в контрольной группе $(11,6 \pm 1,0 \%)$, хотя различия не достигали уровня значимости.

При оценке распространения частот генотипов в зависимости от степени тяжести заболевания выявлено следующее: у больных БА легкой степени тяжести отмечено незначительное повышение гетерозигот- ного генотипа (64V / I) по сравнению с контрольной группой $(25,0 \pm 6,8 \%$ и $19,0 \pm 1,9 \%$ соответственно; $p=0,637)$. Наоборот, у пациентов со среднетяжелой БА генотип $64 \mathrm{~V} /$ I встречался реже, чем в контроле $(14,7 \pm 6,1 \%$ и $19,0 \pm 1,9 \%$ соответственно; $p=0,547)$. При этом у больных тяжелой БА частота генотипов гена CCR2 была идентичной группе контроля. Выявленные различия в характере распределения частот генотипов между больными БА с различной степенью тяжести статистически недостоверны (табл. 6).

Частота аллеля I гена CCR5 у больных легкой БА была выше, чем в контрольной группе $(13,9 \pm 3,9 \%$ и $11,6 \pm 1,0 \%$ соответственно; $p=0,585)$, а среди больных среднетяжелой и тяжелой БА - ниже $(7,4 \pm$ $3,2 \% ; 9,4 \pm 5,1 \%$ и $11,6 \pm 1,0 \%$ соответственно; $p=0,426$ и $p=1,0$ соответственно). В целом сравнительный анализ распределения частот аллелей гена CCR2 у больных БА в зависимости от формы заболевания не выявил статистически достоверных различий с контрольной группой.

Был проведен сравнительный анализ распросранения частот генотипов и аллелей гена CCR2

Таблица 7

Частота генотипов и аллелей полиморфизма гена CCR2 среди родственников, $M \pm m$

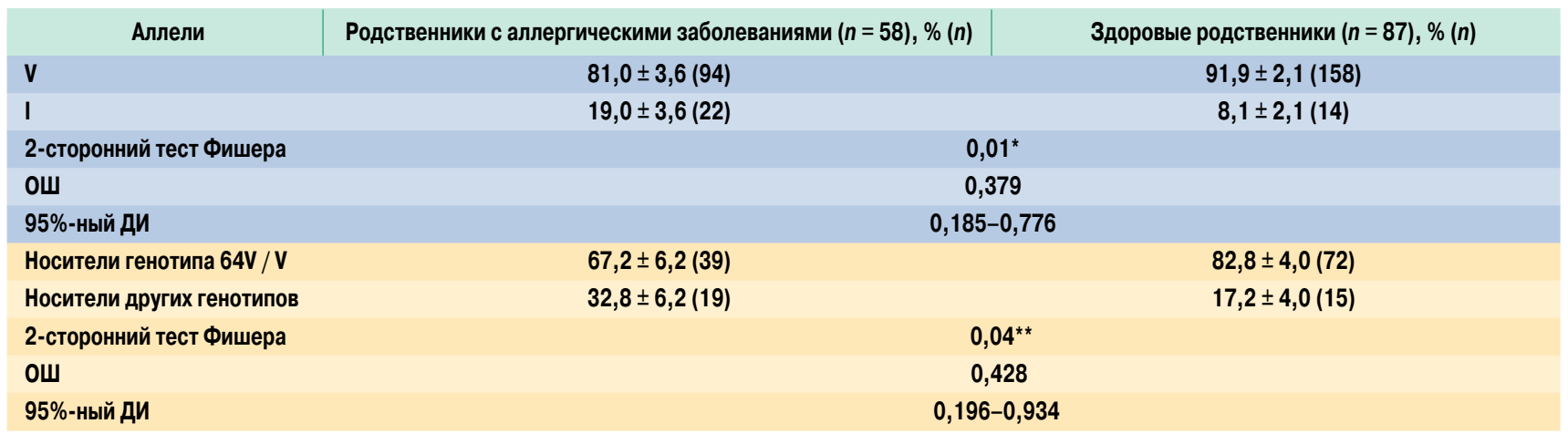

Примечание: * - достигнутый уровень значимости при сравнении частоты аллелей; ** - достигнутый уровень значимости при сравнении частоты генотипов. 
у родственников больных, страдающих БА (табл. 4). При сравнении частот генотипов полиморфизма гена CCR2 в группе родственников, имеющих различные аллергические заболевания, с популяционной контрольной группой статистически достоверные различия не установлены $(p=0,095)$. Также статистически достоверными были различия частот аллелей в группе родственников с аллергией в сравнении с популяционной контрольной группой $(p=0,035)$. Аллель 64I гена CCR2 чаще встречался в группе родственников с аллергическими заболеваниями, по сравнению с контрольной группой (ОШ $-1,77$; 95\%-ный ДИ - 1,07-2,95).

Наряду с этим, наблюдалось статистически достоверное увеличение частоты гомозиготного генотипа $64 \mathrm{~V} / \mathrm{V}$ среди здоровых родственников по сравнению с группой родственников с аллергическими заболеваниями $(82,8 \pm 4,0 \%$ и $67,2 \pm 6,2 \%$ соответственно; ОШ - 0,4; 95\%-ный ДИ - 0,196-0,93; $p=0,04)$, как показано в табл. 7. Также выявлены статистически значимые различия в распределении частот аллелей между группами родственников с аллергией и здоровыми родственниками. Доля носителей аллеля 64I была достоверно выше в группе родственников с аллергией $(p=0,01)$ по сравнению со здоровыми. ОШ носительства аллеля 64I в группе родственников с аллергией было в 2,6 раза выше, чем в группе здоровых родственников (95\%-ный ДИ - 1,3-5,4).

\section{Заключение}

Таким образом, в результате проведенного исследования I / D полиморфизма гена CCR5 в кодирующей области выявлено отсутствие статистически достоверных различий частоты генотипов и аллелей в выборке больных БА и их родственников, по сравнению с популяционным контролем. Среди всех пациентов с БА частота генотипа ID была ниже, а носительство аллеля D встречалось гораздо реже, чем в группе контроля. При этом выявлены существенные отличия в распределении частот генотипов и аллелей по гену CCR5 у больных аллергической и неаллергической БА в сравнении с контролем. Группа больных аллергической БА характеризовалась низкой частотой встречаемости генотипа ID и редким носительством аллеля D в сравнении с группой контроля. Анализ распределения генотипов полиморфизма гена CCR5 в выборке пациентов с БА показал статистически значимую ассоциацию генотипа II с легким течением заболевания. По мере нарастания степени тяжести БА прослеживалась тенденция к накоплению гетерозиготного генотипа ID и аллеля D, по сравнению с контрольной группой. Наконец, носители гомозиготного генотипа DD и аллель D встречались чаще среди родственников I, II и III степени, чем в контрольной группе. Полученные данные о более низкой частоте встречаемости делеционного аллеля гена хемокинового рецептора CCR5 у больных БА по сравнению с популяционным контролем подтверждаются опублико- ванными исследованиями [18]. Это позволяет сделать вывод о том, что аллель D гена хемокинового рецептора CCR5 можно считать протективным фактором развития БА. Полиморфизм гена хемокинового рецептора CCR5 ассоциирован с фенотипическим проявлением значимых для БА признаков и является важной компонентой наследственной подверженности аллергической БА.

При сравнении частот генотипов и аллелей полиморфизма V64I гена CCR2 в среди больных БА и в контрольной группе различий не выявлено. Установлено, что частота генотипа 64V/V гена CCR2 cpeди здоровых родственников была больше, чем среди родственников с аллергическими заболеваниями $(82,8 \pm 4,0 \%$ и 67,2 $\pm 6,2 \%$ соответственно; ОШ $0,4 ; 95 \%$-ный ДИ $-0,2-0,9 ; p=0,045)$. Можно предположить, что носительство гомозиготного генотипа $\mathrm{V} / \mathrm{V}$ является протективным фактором развития аллергии. Доля носителей аллеля 64I выше среди родственников с аллергией $(p=0,01)$ по сравнению с группой здоровых родственников. ОШ носительства аллеля 64I в группе родственников с аллергией в 2,6 раза выше, чем в группе здоровых родственников $(95 \%$-ный ДИ - 1,3-5,4). На основании этих значений можно считать, что аллель 64I вносит определенный вклад в развитие аллергических заболеваний. Носительство аллеля 64I является фактором, предрасполагающим к развитию аллергии.

На основании данных литературы и проведенного исследования можно полагать, что возникновению БА во многих случаях способствует наследственная предрасположенность. Изучение генов-кандидатов БА остается несомненно актуальным.

\section{Литература}

1. Чучалин А.Г. Генетические аспекты бронхиальной астмы. Пульмонология 1999; 4: 6-10.

2. Пузырев В.П. (ред.). Наследственность и болезни легких: Учеб. пособие. Томск; 2007.

3. Петрова И.В., Козырицкая Д.В., Камалтынова Е.М., Огородова Л.М. Ассоциация полиморфизма промоторной области генов NO-синтаз с развитием бронхиальной астмы. Пульмонология 2007; 4: 52-55.

4. Пузырев В.П., Степанов В.А., Назаренко С.А. Геномные исследования наследственной патологии и генетического разнообразия сибирских популяций. Молекул. биол. 2004; 38 (1): 129-138.

5. Огородова Л.М., Федорова О.С., Брагина Е.Ю. идр. Генетические маркеры бронхиальной астмы у детей, больных атопическим дерматитом. Пульмонология 2007; 4 : 37-40.

6. Cookson W.O.C., Moffatt M.F. Genetics of asthma and allergis disease. Hum. Mol. Genet. 2000; 9 (16): 2359-2364.

7. Combadiere C., Ahuja S.K., Tiffany H.L., Murphy P.M. Cloning and functional expression of CC CKR5, a human monocyte CC chemokine receptor selective for MIP-1 (alpha), MIP-1(beta), and RANTES. J. Leukoc. Biol. 1996; 60 (1): 147-152.

8. Samson M., Labbe O., Mollereau C. et al. Molecular cloning and functional expression of a new human CC-chemokine receptor gene. Biochemistry 1996; 35 (11): 3362-3367. 
9. Alkhatib G., Combadiere C., Broder C.C. et al. CC CKR5: a RANTES, MIP-1alpha, MIP-1beta receptor as a fusion cofactor for macrophage-tropic HIV-1. Science 1996; 272 (5270): 1955-1958.

10. Dean M., Carrington M., Winkler C. et al. Genetic restriction of HIV-1 infection and progression to AIDS by a deletion allele of the CKR5 structural gene. Hemophilia Growth and Development Study, Multicenter AIDS Cohort Study, Multicenter Hemophilia Cohort Study, San Francisco City Cohort, ALIVE Study. Science 1996; 273 (5283): 1856-1862.

11. Martinson J.J., Chapman N.H., Rees D.C. et al. Global distribution of the CCR5 gene 32-basepair deletion. Nat. Genet. 1997; 16 (1): 100-103.

12. Лимборская С.А., Хуснутдинова Э.К., Балановская Е.В. Этногеномика и геногеография народов Восточной Европы. М.: Наука, 2002.

13. Samson M., Libert F., Doranz B.J. et al. Resistance to HIV-1 infection in caucasian individuals bearing mutant alleles of the CCR-5 chemokine receptor gene. Nature 1996; 382 (6593): 722-725.

14. Mulherin S.A., O'Brien T.R., Ioannidis J.P. Effects of CCR5Delta32 and CCR2-64I alleles on HIV-1 disease progression: the protection varies with duration of infection. AIDS 2003; 17 (3): 377-387.

15. Орлова Ю.Ю., Алифирова В.М., Чердынцева Н.В., Гервас П.А. Полиморфизм гена хемокинового рецептора CCR5 у больных рассеянным склерозом в Сибирском регионе. Бюл. сиб. мед. 2006; 3: 98-104.

16. Севастьянова Н.В., Чердынцева Н.В., Белявская В.А. и др. Полиморфизм гена хемокинового рецептора CCR5 и его взаимосвязь с опухолевыми маркерами у больных раком легкого. Рос. биотерапевт. журн. 2004; 2: 39.

17. Murakami T., Cardones A.R., Hwang S.T. Chemokine receptors and melanoma metastasis. J. Dermatol. Sci. 2004; 36: 71-78.

18. Васильева М.В. Генетические и иммунологические параллели у больных раком легкого и бронхиальной астмой: Автореф. дис. ... канд. мед. наук. Томск; 2006.

19. Логвиненко Н.И. Некоторые особенности этиологии, клиники, влияние генетических факторов на формирование воспаления (на модели современных пневмоний в Новосибирске): Дис. ... Д-ра мед. наук. Новосибирск; 2003.

20. Егорова Н.Е., Логвиненко Н.И., Максимов В.Н. Особенности полиморфизма некоторых макрофаг специфических генов у больных с тяжелой пневмонией в условиях Севера. Пульмонология: Прил.: Национальный конгресс по болезням органов дыхания, 17-й: Сборник резюме. Казань; 2007. 122, № 288.

21. Максимов В.Н. Связь наследственной отягощенности и полиморфизма некоторых генов-кандидатов с сердечно-сосудистыми заболеваниями и их факторами риска в городской популяции Западной Сибири: Дис. ... Д-ра мед. наук. Новосибирск; 2007.
22. Gonzalez P., Alvarez R., Batalla A. et al. Genetic variation at the chemokine receptors CCR5/CCR2 in myocardial infarction. Genes Immun. 2001; 2 (4): 191-195.

23. Szalai C., Duba J., Prohaszka Z. et al. Involvement of polymorphisms in the chemokine system in the susceptibility for coronary artery disease (CAD). Coincidence of elevated $\mathrm{Lp}(\mathrm{a})$ and MCP-1 -2518 G/G genotype in CAD patients. Atherosclerosis 2001; 158 (1): 233-239.

24. Эткина И.А. Клинико-генетические ассоциации у детей, больных бронхиальной астмой: Автореф. дис. ... канд. мед. наук. Уфа; 2000.

25. O'Regan A.W., Berman J.S. The gene for acute sarcoidosis? Am. J. Respir. Crit. Care Med. 2003; 168: 1162-1166.

26. Васинская O.A., Корнеясова Н.A. CCR2 и CCR5 гены в группе этнических шорцев. Olga.Vasinskaja@rambler.ru. УДК 577.21.

27. Воевода М.И., Устинов С.Н., Юдин Н.С. и др. Связь полиморфизма гена хемокинового рецептора CCR2 с инфарктом миокарда. Докл. РАН 2002; 385 (2): 279-282.

28. Kim Y., Kuzie. W.A., Feldman S., Fu S.M. PMID:11290802.

29. Глобальная стратегия лечения и профилактики бронхиальной астмы. Совместный доклад Национального института сердца, легких и крови США, Всемирной организации здравоохранения. Пересмотр 2002.: Пер. с англ.; Под ред. А.Г.Чучалина и др. М.: Изд-во "Атмосфера"; 2002. 160 c.

30. Глобальная стратегия лечения и профилактики бронхиальной астмы. Совместный доклад Национального института сердца, легких и крови США, Всемирной организации здравоохранения. Пересмотр 2006.: Пер. с англ. под ред. А.Г.Чучалина и др. М.: Изд-во "Атмосфера"; 2007.

31. Yudin N.S., Vinogradov S.V., Potapova T.A. et al. Distribution of CCR5-delta 32 gene deletion across the Russian part of Eurasia. Hum. Genet. 1998; 102 (6): 695-698.

\section{Информация об авторах}

Черкашина Ирина Ивановна - к. м. н., доцент кафедры внутренних болезней №1 КрасГМУ им. проф. В.Ф.Войно-Ясенецкого; тел.: (391) 26429-80; e-mail: cherkashina@list.ru

Никулина Светлана Юрьевна - д. м. Н., проф., проректор по учебной работе КрасГМУ им. проф. В.Ф.Войно-Ясенецкого; тел.: (391) 220-09-14; e-mail: nicoulina@mail.ru

Шульман Владимир Абрамович - д. м. н., проф., зав. кафедрой внутренних болезней № 1 КрасГМУ им. проф. В.Ф.Войно-Ясенецкого; тел.: (391) 264-29-80

Логвиненко Надежда Ивановна - д. М. н., проф. кафедры терапии ФПК ППВ НГМУ; тел.: (3832) 20-86-45; e-mail: nadejda-logvinenko@yandex.ru Максимов Владимир Николаевич - д. М. н., старший научный сотрудник НИИ терапии СО РАМН; тел.: (383) 264-25-16; e-mail: medik11 @mail.ru.

Воевода Михаил Иванович - д. М. Н., проф., директор НИИ терапии СО РАМН; тел.: (383) 264-25-16

Чернова Анна Александровна - ассистент кафедры внутренних болезней № 1 КрасГМУ им. проФ. В.Ф.Войно-Ясенецкого; тел.: (391) 264-29-80; e-mail: anechkachernova@yandex.ru

Поступила 29.10.09 (с) Коллектив авторов, 2010 УдК 616.248-056.7 